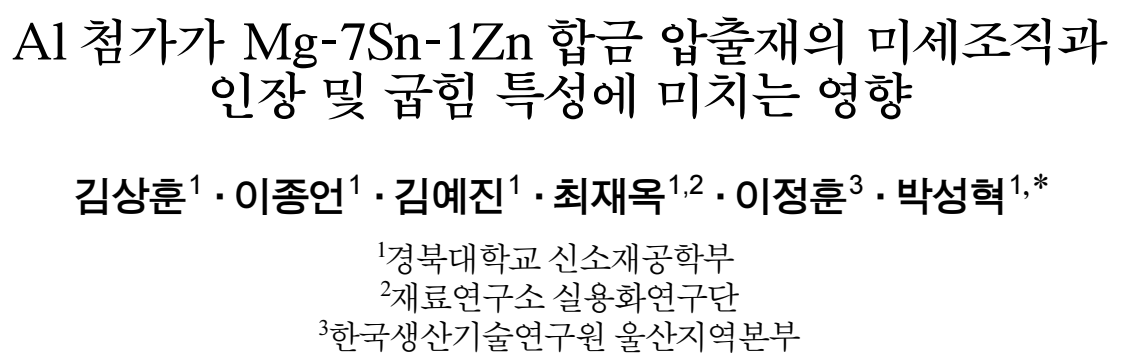

\title{
Effect of Al Addition on the Microstructure, Tensile Properties, and Bendability of Extruded Mg-7Sn-1Zn Alloy
}

\author{
Sang-Hoon Kim¹, Jong Un Lee ${ }^{1}$, Ye Jin Kim ${ }^{1}$, Jae Ok Choi ${ }^{1,2}$, \\ Jeong-Hun Lee ${ }^{3}$, and Sung Hyuk Park ${ }^{1, *}$ \\ ${ }^{1}$ School of Materials Science and Engineering, Kyungpook National University, Daegu 41566, Republic of Korea \\ ${ }^{2}$ Implementation Research Division, Korea Institute of Materials Science, Changwon 51508, Republic of Korea \\ ${ }^{3}$ Ulsan Regional Division, Korea Institute of Industrial Technology, Ulsan 44413, Republic of Korea
}

\begin{abstract}
The effect of $\mathrm{Al}$ addition on the microstructure and mechanical properties of extruded $\mathrm{Mg}$-Sn based alloy is investigated by adding $1 \mathrm{wt} \% \mathrm{Al}$ to the $\mathrm{Mg}-7 \mathrm{Sn}-1 \mathrm{Zn}$ alloy and indirectly extruding the billets with and without the $\mathrm{Al}$ addition. The $\mathrm{Al}$ addition promotes dynamic recrystallization (DRX) behaviour during hot extrusion, which results in an increase in the area fraction of dynamically recrystallized (DRXed) grains and a decrease in the width of unDRXed grains of the extruded alloy. In addition, dynamic precipitation during extrusion is also accelerated by the $\mathrm{Al}$ addition owing to the decrease in $\mathrm{Sn}$ solubility in the $\mathrm{Mg}$ matrix, thereby increasing the amount of $\mathrm{Mg}_{2} \mathrm{Sn}$ precipitates and decreasing their size. The increased amount of fine precipitates, and the reduced amount of coarse unDRXed grains, lead to a reduction in the average grain size of the extruded alloy. The $\mathrm{Al}$ addition significantly improves tensile properties (i.e., strength and ductility) and 3 point bending strength of the extruded alloy. The improvement in the tensile and bending strengths is attributed to the combined effects of grain-boundary hardening by the reduced grain size, precipitation hardening by more abundant precipitates, and solid-solution hardening by dissolved $\mathrm{Al}$ atoms. The increase in the tensile elongation results from the decrease in the amount and size of the coarse unDRXed grains because $\{10-11\}$ contraction and $\{10-11\}-\{10-12\}$ double twins, which can act as initiation sites of microcracks, easily occur under tension along the extrusion direction in the coarse grains. However, the increased amount of precipitates and the reduced grain size accelerate the formation of shear bands and suppress the activation of $\{10-12\}$ twinning in the upper side of the bending sample, which consequently results in a deterioration in the bending formability of the extruded alloy.
\end{abstract}

(Received August 21, 2017; Accepted October 31, 2017)

Keywords: magnesium alloy, extrusion, recrystallization, precipitation, tensile properties

\section{1. 서 론 \\ 최근 심각한 지구온난화 문제로 인해 온실가스 배출 규}

제가 강화됨에 따라, 자동차 산업에서는 에너지 효율을 향 상시키고 이산화탄소 배출을 저감시키기 위해 수송기기의 경량화에 대한 관심이 증대하고 있다. 마그네슘합금은 상 용되는 구조용 금속소재 중 가장 비중이 낮으며 높은 비강 도를 가지고 있어 수송기기 경량화에 적합한 소재로 알려

*Corresponding Author: Sung Hyuk Park 져 있다 [1-3]. 마그네슘합금은 주로 주조재로 많이 사용되 [Tel: +82-53-950-5565, E-mail: sh.park@knu.ac.kr] Copyright (c) The Korean Institute of Metals and Materials 
물성을 가지고 있어 수송기기용 부품으로서의 큰 잠재력을 가지고 있기 때문에, 최근 마그네슘합금 압연재와 압출재 개발에 대한 연구가 활발히 진행되고 있다 [4-6]. 압연 공 정의 경우 최종 판재 제조를 위해 여러 차례의 열간 압연 과 중간 열처리를 반복적으로 수행해야 하지만, 압출은 단 한번의 공정으로 다양한 형태의 압출재를 얻을 수 있는 장 점이 있다. 압출에 있어서 압출속도가 증가함에 따라 압출 중 발생되는 가공 발열량이 높아지게 되는데, AZ80 $(\mathrm{Mg}$ $8 \mathrm{Al}-0.5 \mathrm{Zn}, \mathrm{wt} \%$ )과 $\mathrm{ZK} 60(\mathrm{Mg}-6 \mathrm{Zn}-0.5 \mathrm{Zr}, \mathrm{wt} \%)$ 같은 고 강도 상용 마그네슘합금에서 형성되는 $\mathrm{Mg}_{17} \mathrm{Al}_{12}$ 또는 $\mathrm{MgZn}_{2}$ 이차상은 압출 중 발생되는 높은 가공 발열로 인한 용융이 일어나서 표면에 열간 균열이 발생하게 된다 [7]. 이로 인해, 고강도 상용 마그네슘합금은 결함없이 압출재 를 제조할 수 있는 최대압출속도가 $5 \mathrm{~m} / \mathrm{min}$ 이하로 낮은 압출성을 가지게 되어, 생산성이 저하되고 최종 제품 단가 가 향상된다는 문제점이 있다. 반면, $\mathrm{Mg}-\mathrm{Sn}$ 계 합금에서는 $770{ }^{\circ} \mathrm{C}$ 의 용융 온도를 가지는 열적으로 안정한 $\mathrm{Mg}_{2} \mathrm{Sn}$ 상이 형성되기 때문에 압출 중 가공 발열로 인한 높은 온도에도 이차상의 용융이 쉽게 발생하지 않는다. 이러한 우수한 압 출성으로 인해, 최근 $\mathrm{Mg}-\mathrm{Sn}$ 계 합금에 대한 연구가 활발히 이루어지고 있다 [8-13]. 최근 연구에 따르면, $7 \mathrm{wt} \% \mathrm{Sn}$ 이 함유된 Mg- $7 \mathrm{Sn}$ 계 합금은 $27 \mathrm{~m} / \mathrm{min}$ 의 높은 압출속도에 서도 표면결함 없이 건전한 압출재를 제조할 수 있는 것 으로 보고되었다 [12]. 게다가, 압출 중 동적 석출로 형성 되는 미세한 $\mathrm{Mg}_{2} \mathrm{Sn}$ 이차상들이 고르게 분포되기 때문에, 동일한 조건에서 압출된 상용마그네슘 합금 $\mathrm{AZ80}$ 압출재 보다 우수한 항복강도를 나타낸다 [13].

마그네슘 압출재의 미세조직 및 기계적 특성은 온간 또는 열 간 압출 중에 발생하는 동적 재결정(dynamic recrystallization, $\mathrm{DRX}$ 과 동적 석출(dynamic precipitation) 거동과 밀접한 관련이 있다. 동적 재결정과 동적 석출은 압출 중에 축적 되는 내부 변형(internal strain)과 전위(dislocation)를 해소하 기 위해 새로운 결정립을 형성하거나 과고용(supersatration) 되어 있는 용질 원소가 미세한 석출물로 형성되는 것으로, 각각 결정립계 강화(grain-boundary hardening)와 석출 강 화(precipitation hardening) 효과를 얻을 수 있기 때문이다. 이러한 동적 재결정과 동적 석출의 거동은 합금화를 통해 달라질 수 있다고 알려져 있다 [14-22]. 합금원소의 첨가로 인해 형성되는 열적으로 안정한 상들이 압출 중 동적 재결 정의 핵 생성 장소를 제공함으로써 동적 재결정을 촉진한 다고 보고되고 있다 [18-20]. 한편, 첨가되는 합금원소가 기존 석출물의 형성에 필요한 합금원소와 반응하여 새로운 상을 형성하게 되면, 압출 중 형성되는 동적 석출물의 양
이 감소하여 강도에 악영향을 미칠 수도 있다 [21,22]. 이 와 같이 첨가되는 합금원소의 종류에 따라 동적 재결정과 동적 석출 거동이 달라지는데, 합금원소 중 $\mathrm{Al}$ 은 $\mathrm{Sn}$ 과 반 응하여 새로운 상을 형성하지 않을 뿐만 아니라 고용 강화 및 석출 강화 효과 또한 기대할 수 있기 때문에, $\mathrm{Mg}-\mathrm{Sn}$ 계 합금 압출재의 강도 향상에 적합한 합금원소로 볼 수 있다. 하지만, 우수한 강도와 압출성을 가지는 $\mathrm{Mg}-7 \mathrm{Sn}$ 계 합금에서 $\mathrm{Al}$ 이 첨가되었을 때, 동적 재결정과 동적 석출 거동에 미치는 영향에 대한 상세한 연구가 부족하다. 또한, 압출 공정을 통해 제조된 마그네슘 합금 봉재(rod), 선재 (wire), 판재(plate), 각재(bar), 관재(tube), 형재(shape) 들 은 구조재료의 부품으로 사용되기 위해 많은 경우 성형 공 정을 거치게 된다. 특히, 압출재의 경우 굽힘 성형을 통해 형상을 제어하는 경우가 많음에도 불구하고, 현재까지 $\mathrm{Mg}$ $7 \mathrm{Sn}$ 계 합금에 대한 굽힘 성형성에 대한 연구를 전무한 실정이다. 따라서, 본 연구에서는 TZ71 $(\mathrm{Mg}-7 \mathrm{Sn}-1 \mathrm{Zn}$, $\mathrm{wt} \%)$ 에 $1 \mathrm{wt} \% \mathrm{Al}$ 의 첨가하여 압출재의 미세조직과 인장 및 굽힘 특성의 변화를 분석하고 이를 동적 재결정과 동적 석출 거동 관점에서 면밀히 조사하였다.

\section{2. 실험 방법}

본 연구에서 $\mathrm{TZ71}(\mathrm{Mg}-7 \mathrm{Sn}-1 \mathrm{Zn}, \mathrm{wt} \%)$ 합금과 $\mathrm{Al}$ 이 $1 \mathrm{wt} \%$ 가 첨가된 TZA711 (Mg-7Sn-1Zn-1Al, wt\%) 합금 을 사용하였다. 압출을 위한 빌렛(billet)을 제조하기 위하여, 도가니에 순수 마그네슘을 장입하고 $720^{\circ} \mathrm{C}$ 에서 용해 시킨 후 $\mathrm{Sn}, \mathrm{Zn}, \mathrm{Al}$ 의 합금원소를 첨가하여 20 분 동안 유지하 였고, 용해 중 용탕의 산화를 방지하기 위해 $\mathrm{CO}_{2}$ 와 $\mathrm{SF}_{6}$ 혼합 가스를 주입하였다. 안정화된 용탕을 $210^{\circ} \mathrm{C}$ 로 예열 된 스틸몰드(steel mold)에 출탕하여 압출 빌렛을 제조하였 다. 제조된 빌렛의 균질화 열처리는 PANDAT software를 통해 얻어진 평형 상태도에서의 용융 온도를 고려하여 $\mathrm{TZ71}$ 합금은 $510{ }^{\circ} \mathrm{C}$, TZA711 합금은 $500{ }^{\circ} \mathrm{C}$ 에서 24 시 간 동안 진행하였으며 (표 1), 과포화 상태를 만들기 위해 수냉하였다. 압출 빌렛의 화학적 조성을 확인하기 위해 유 도 결합 플라즈마 질량분광기 (inductively coupled plasma mass spectrometry, ICP-MS; Thermo Xseries $\mathrm{II}$ 를 이용하여 합금원소의 정량 분석을 실시하였고, 목표 한 함량과 아주 근사한 값을 가지는 것을 확인하였다 (표 2). 균질화 처리된 빌렛을 직경 $50 \mathrm{~mm}$ 로 가공 후 $250^{\circ} \mathrm{C}$ 의 온도에서 1 시간 동안 예열하고, 500 ton의 용량을 가지 는 직간접 겸용 압출기를 이용하여 $1 \mathrm{~mm} / \mathrm{s}$ 의 램속도 $(\mathrm{ram}$ speed)로 $250{ }^{\circ} \mathrm{C}$ 에서 $20: 1$ 의 압출비(extrusion ratio)로 간 
접압출(indirect extrusion)을 실시하였다. 압출재의 압출속 도는 $1.2 \mathrm{~m} / \mathrm{min}$ 에 해당된다.

$\mathrm{Al}$ 첨가에 따른 미세조직 변화를 관찰하기 위해 균질화 재의 단면과 압출재의 길이방향 단면(logitudinal crosssection)을 광학현미경(optical microscope)으로 관찰하였다. 각 압출재의 재결정 분율(DRX fraction)은 비교적 높은 배율 $(\times 200)$ 에서 촬영한 다수의 광학현미경 사진을 결합하 여 $20.2 \mathrm{~mm}^{2}$ 의 넓은 영역에 대하여 이미지 분석기(image analyzer)를 이용하여 재결정이 되지 않은 영역을 계산하여 측정되었다. 압출재의 평균 결정립 크기와 분포는 전자 후 방 산란 회절 기법(electron backscatter diffraction, $\mathrm{EBSD})$ 을 이용하여 측정하였다. 압출 중 형성된 동적 석출 물을 전계방사형 주사전자현미경(field emmission scanning electron microscope, FE-SEM)을 이용해 관찰하였고, Xray 회절분석기(X-ray diffractometer, $\mathrm{XRD}$ )로 정성 분석을 수행하였다. XRD는 $40 \mathrm{kV}, 100 \mathrm{~mA}$ 의 조건에서 $25^{\circ}-$ $50^{\circ}$ 의 범위에 걸쳐 분당 $2^{\circ}$ 의 스캔 속도로 측정되었다. 동 적 석출물의 정량 분석을 위해 균질화재와 압출재의 전기 비저항을 측정하였다. 전기비저항은 digital multimeter (Sourcemeter)와 nanovoltmeter를 이용하여 상온에서 $0.1 \mathrm{~A}$ 의 조건으로 측정되었으며, 10 번의 측정 후 평균 값을 구 하여 사용하였다. 압출재의 기계적 특성을 비교하기 위해 상온 인장 시험을 시행하였다. 인장시험편은 ASTM E8/ $\mathrm{E} 8 \mathrm{M}$ 규격을 따랐으며, 게이지 부(gage section)의 직경과 길이가 각각 $6 \mathrm{~mm}, 25 \mathrm{~mm}$ 을 가지는 인장시험편을 Instron 4206 시험기를 이용하여 $0.001 \mathrm{~s}^{-1}$ 의 변형률 속도로 인장시험을 수행하였다. 압출재의 굽힘특성은 3점 굽힘시 험(3-point bending test)으로 평가하였다. ASTM E290

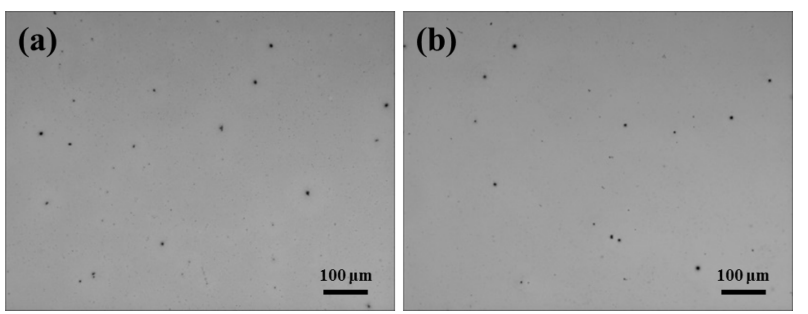

Fig. 1. Optical micrographs of homogenized (a) TZ71 and (b) TZA711 billets.

Table 1. Calculated melting temperatures and conducted homogenization heat treatment conditions.

\begin{tabular}{c|c|c|c|c}
\hline \multirow{2}{*}{ Alloy } & Calculated & \multicolumn{3}{|c}{ Homogenization condition } \\
\cline { 3 - 5 } & $\mathrm{T}_{\mathrm{m}}\left({ }^{\circ} \mathrm{C}\right)$ & Temp. $\left({ }^{\circ} \mathrm{C}\right)$ & Time $(\mathrm{hr})$ & Phase diagram zone \\
\hline TZ71 & 572 & 510 & 24 & $a$-Mg single phase \\
\hline TZA711 & 551 & 500 & 24 & $a$-Mg single phase \\
\hline
\end{tabular}

규격에 따라 상부 핀과 하부 지지대의 직경이 $10 \mathrm{~mm}$ 이고, 하부 지지대간의 거리가 $28 \mathrm{~mm}$ 인 3점 굽힘시험용 지그 를 사용하였다. 직경 $6 \mathrm{~mm}$, 길이 $50 \mathrm{~mm}$ 인 굽힘시험편을 Instron 5985 시험기를 이용하여 $10 \mathrm{~mm} / \mathrm{min}$ 의 cross-head 속도에서 굽힘시험을 수행하였다.

\section{3. 결과 및 고찰}

그림 1 은 압출 전 균질화 열처리된 빌렛들의 미세조직을 나타낸 것으로, TZ71 합금과 TZA711 합금 모두 균질화 열처리를 통해 $\mathrm{Mg}_{2} \mathrm{Sn}$ 이차상이 $\alpha-\mathrm{Mg}$ 기지 내로 완전히 고용된 것을 알 수 있다. 또한, 균질화 처리된 TZA711 합금에서는 $\mathrm{Mg}_{17} \mathrm{Al}_{12}$ 이차상도 관찰되지 않았으며, 이는 수행된 균질화 열처리 온도가 두 합금 모두 $\alpha-\mathrm{Mg}$ 단상 구간에 위치하고 있기 때문에 주조 중에 형성된 모든 이차 상이 기지 내로 고용되었다고 볼 수 있다 (표 1). 하지만, 균질화 열처리 후에도 고용되지 않고 남아있는 작은 상들 이 관찰되었다. TZ71 합금에서 고용되지 않고 남아있는 상들은 빌렛 제조를 위해 사용된 소재에 포함되어 있었거 나 주조 과정 중 혼입된 $\mathrm{Fe}$ 게재물이며, TZA711 합금에 는 첨가된 $\mathrm{Al}$ 과 반응하여 형성된 $\mathrm{Al}-\mathrm{Fe}$ 상으로 $\mathrm{EDS}$ 분석 을 통해 확인되었다. 하지만, TZ71 합금에서의 $\mathrm{Fe}$ 게재물 과 TZA711 합금에서의 $\mathrm{Al}-\mathrm{Fe}$ 상의 양이 매우 적기 때문에 압출 중 거동에 거의 영향을 미치지 않았을 것으로 사료된 다. 그림 2는 TZ71 압출재와 TZA711 압출재의 길이단면 을 광학현미경으로 관찰한 미세조직 사진을 나타낸다. 두 압출재 모두 미세조직 사진 상에서 비교적 어둡게 보이는 동적 재결정된 결정립(DRXed grain) 부분과 밝게 보이는 재결정 되지 않은 결정립(unDRXed grain) 부분으로 이루 어진 bimodal 미세조직을 가지고 있다. 압출 동안에 가해 지는 큰 변형에 의해 전위들이 소재 내에 축적되고 이를 해소하기 위해 연화기구(softening mechanism)인 동적 재 결정이 발생하게 되면 새로운 미세한 결정립이 형성된다. 하지만, 동적 재결정이 일어나지 못한 초기 빌렛의 결정립

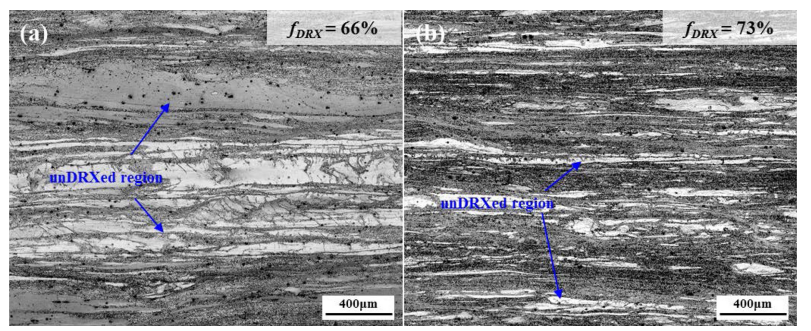

Fig. 2. Optical micrographs of extruded (a) TZ71 and (b) TZA711 alloys. $f_{\mathrm{DRX}}$ denotes the area fraction of recrystallized grains. 

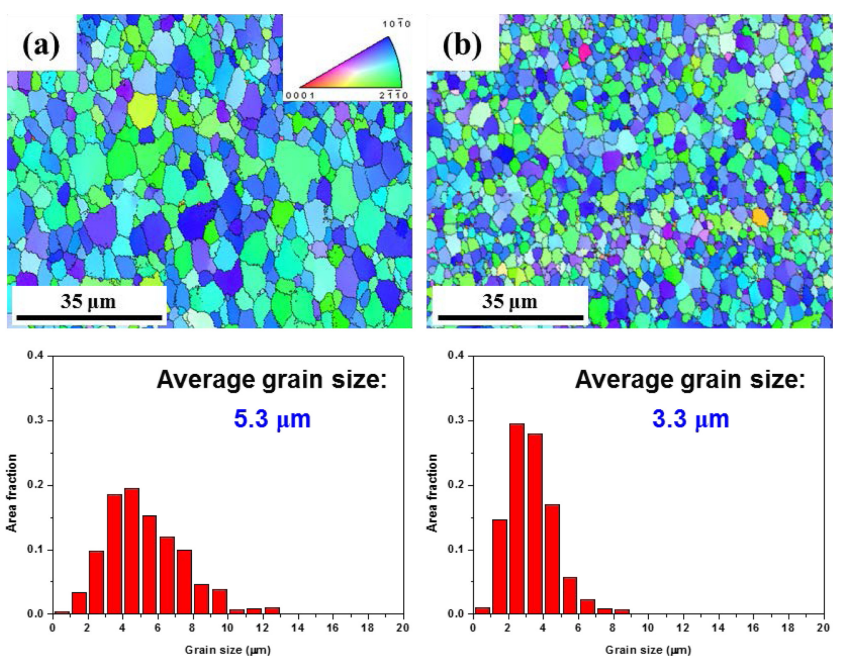

Fig. 3. EBSD inverse pole figure maps and grain size distributions in DRXed region of extruded (a) TZ71 and (b) TZA711 alloys.
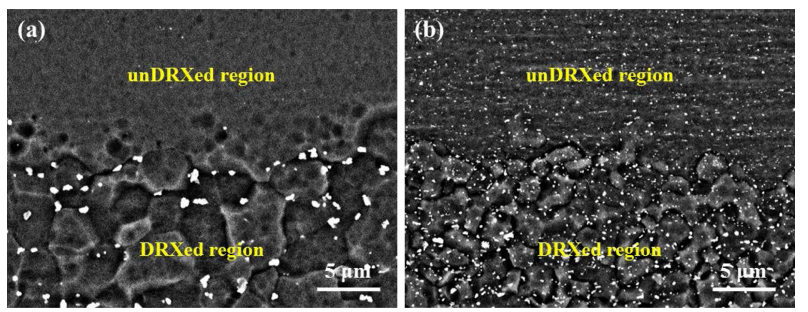

Fig. 4. SEM micrographs showing $\mathrm{Mg}_{2} \mathrm{Sn}$ precipitates of extruded (a) TZ71 and (b) TZA711 alloys.

들은 압출 방향으로 길게 늘어진 상태로 남아있게 된다 [23-25]. 두 압출재의 재결정 분율을 측정해 본 결과, TZ71 압출재의 경우 $66 \%$ 였고, TZA711 압출재의 경우 $73 \%$ 로, $\mathrm{Al}$ 첨가로 인하여 재결정 분율이 $7 \%$ 가량 향상하 였다. 게다가, 조대한 재결정되지 않은 결정립의 폭 또한 큰 차이를 보였다. TZ71 압출재에서는 재결정되지 않은 결정립들이 $100-400 \mu \mathrm{m}$ 의 폭을 가지는 반면, TZA711 압 출재에서는 비교적 얇은 $~ 100 \mu \mathrm{m}$ 의 폭을 가진다. 이러한 $\mathrm{Al}$ 의 첨가로 야기된 재결정 분율 증가와 재결정되지 않은 결정립의 폭 감소는 $\alpha-\mathrm{Mg}$ 기지 내에 고용된 $\mathrm{Al}$ 용질 원 자들이 압출 동안 야기되는 큰 소성변형하에서 전위의 이 동을 효과적으로 방해하여 전위 엉킴(dislocation tangle)과 전위 축적을 용이하게 하고, 이로 인해 동적 재결정의 핵 생성 장소(nucleation site for DRX)가 증가하여 재결정 거동이 촉진되었기 때문으로 볼 수 있다. 그림 3에서 보듯 이, $\mathrm{EBSD}$ 결과로부터 얻어진 재결정된 결정립의 평균 크 기는 TZ71 압출재에서 $5.3 \mu \mathrm{m}, \mathrm{TZA711}$ 압출재에서는 $3.3 \mu \mathrm{m}$ 로 확인되었으며, 이것은 소량의 $\mathrm{Al}$ 의 첨가로 인해

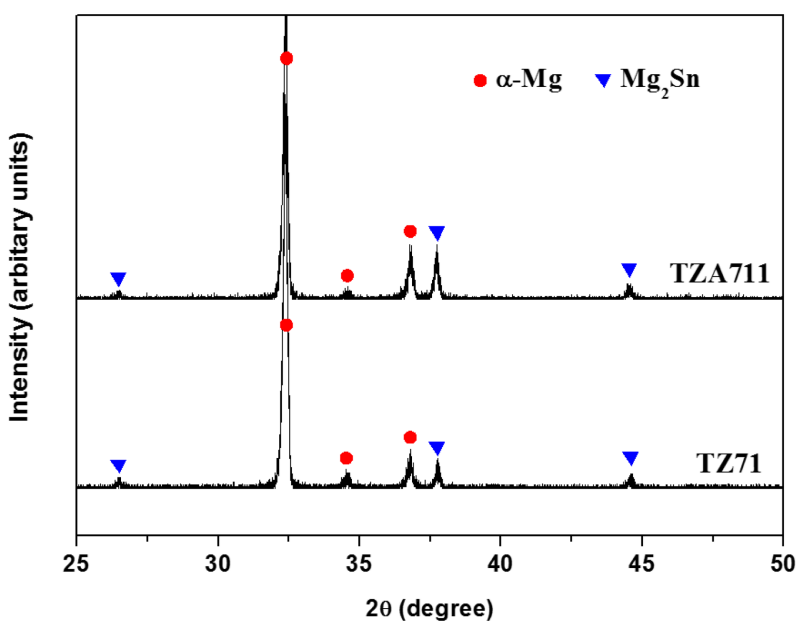

Fig. 5. X-ray diffraction patterns of extruded TZ71 and TZA711 alloys.

재결정된 결정립의 크기가 미세화됨을 의미한다. $\mathrm{Al}$ 의 첨 가에 따른 미세조직 변화를 면밀히 조사하기 위해 두 압출 재의 미세조직을 FE-SEM을 활용하여 고배율로 관찰하였 다. 그림 4의 압출재 미세조직 사진에서 보여지는 바와 같 이, TZ71 압출재는 $0.2-0.7 \mu \mathrm{m}$ 의 크기를 가지는 동적 석 출물이 재결정된 결정립계를 따라서 주로 관찰되었고, 재 결정되지 않은 결정립에서는 관찰되지 않았다. 반면, TZA711 압출재에서는 $0.1 \mu \mathrm{m}$ 이하의 아주 미세하고 많은 동적 석출물이 재결정된 영역과 재결정되지 않은 영역 모 두에서 관찰되었다. 압출재의 최종 미세조직은 압출 중에 형성되는 동적 석출물의 크기와 수에 따라 달라질 수 있다 - 동적 재결정 거동에 의해 새롭게 형성된 재결정된 결정 립들은 압출재에 내재되어 있던 잠열에 의해 결정립 성장 이 일어나서 그 크기가 점차 커지게 된다. 이 때, 이미 형 성된 동적 석출물의 크기가 작을수록, 그리고 수가 많을수 록, 결정립계 고착 효과(grain-bonudary pinning effect)가 강화되어 압출재의 결정립이 미세해진다. 따라서, TZA711 압출재에서의 더 작고 더 많은 양의 석출물들이 결정립 성 장을 효과적으로 방해하여 TZ71 압출재 보다 미세한 재결 정된 결정립을 가지게 된다. 그림 5 는 XRD 결과를 보여 주는 것으로, TZ71과 TZA711 압출재에 형성된 동적 석 출물들은 모두 $\mathrm{Mg}_{2} \mathrm{Sn}$ 상으로 확인되었다. TZA711 합금에 서 $\alpha-\mathrm{Mg}$ 기지 내로 고용되어 있는 $1 \mathrm{wt} \%$ 의 $\mathrm{Al}$ 은 압출 중에 $\mathrm{Mg}_{17} \mathrm{Al}_{12}$ 상으로 석출되지 않고, 압출 후에도 기지 내에 고용 상태로 남아있다. 동적 석출된 $\mathrm{Mg}_{2} \mathrm{Sn}$ 상의 양을 정량적으로 측정하기 위해 TZ71과 TZA711 합금의 균질 화재와 압출재의 전기비저항을 측정하여 그림 6(a)에 나타 내었다. 전기비저항 값은 시료의 기지 내에 고용되어 있는 

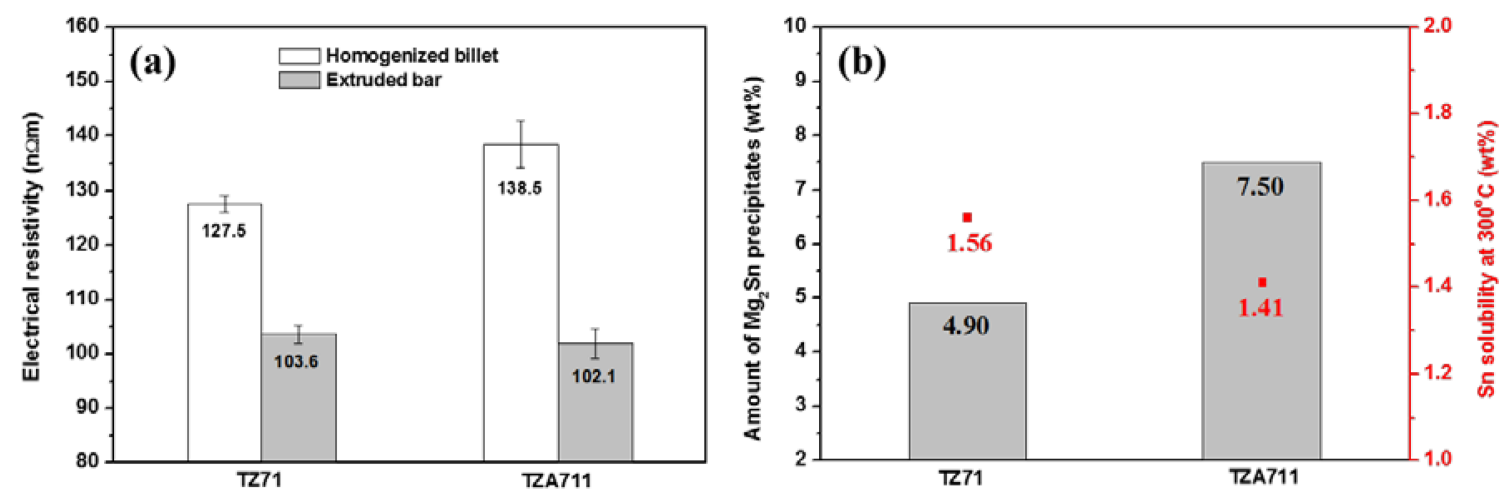

Fig. 6. (a) Variation in electrical resistivity during extrusion and (b) amount of $\mathrm{Mg}_{2} \mathrm{Sn}$ precipitates, which is obtained from measured electrical resistivity values, and Sn solubility at 300 ? of TZ71 and TZA711 alloys, which is calculated with PANDAT software.

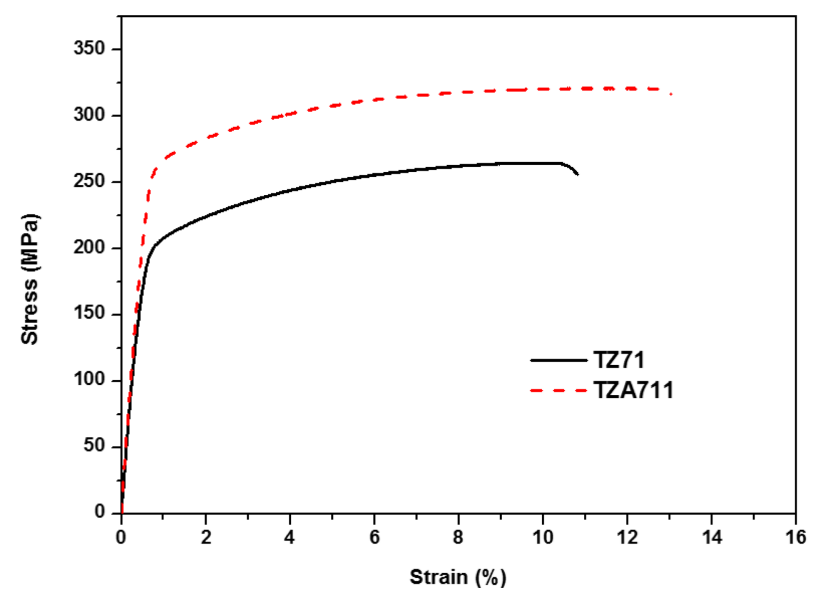

Fig. 7. Tensile stress-strain curves of extruded TZ71 and TZA711 alloys.

원자들의 양이 많을수록 증가하기 때문에 균질화재와 압출 재의 전기비저항 값의 차이를 통해 압출 중에 형성된 동적 석출물의 양을 계산할 수 있다 [26]. 두 합금이 다른 전위 밀도와 결정립 크기를 가지고 있으나, 이전 연구에 따르면 , 마그네슘에서는 이러한 차이가 전기비저항에 큰 영향을 미치지 않는 것으로 보고되고 있다 [27]. TZ71 균질화재 의 전기비저항 값은 $127.5 \mathrm{n} \Omega \mathrm{m}$ 이고, TZA711 균질화재의 전기비저항 값은 $138.5 \mathrm{n} \Omega \mathrm{m}$ 으로 $\mathrm{TZA711}$ 균질화재의 전 기비저항 값이 $\mathrm{TZ71}$ 균질화재의 전기비저항 값 보다 높다 는 것을 알 수 있다. 이는 첨가된 $1 \mathrm{wt} \% \mathrm{Al}$ 이 기지 내
로 고용되어 전기비저항을 $11 \mathrm{n} \Omega \mathrm{m}$ 증가시켰기 때문이다. 압출 후 TZ71과 TZA711 합금에서 전기비저항 값은 모두 감소하였으며, 이는 압출 중에 동적 석출이 발생함에 따라 고용되어 있던 원자의 양이 감소했기 때문이다. TZ71합금 에서 전기비저항 값은 균질화재 $127.5 \mathrm{n} \Omega \mathrm{m}$ 에서 압출재 $103.6 \mathrm{n} \Omega \mathrm{m}$ 로 압출 후에 $23.9 \mathrm{n} \Omega \mathrm{m}$ 만큼 감소한 반면, TZA711 합금에서는 $138.5 \mathrm{n} \Omega \mathrm{m}$ 에서 $102.1 \mathrm{n} \Omega \mathrm{m}$ 로 압출 후에 $36.4 \mathrm{n} \Omega \mathrm{m}$ 만큼 감소하였다. 그림 5 의 $\mathrm{XRD}$ 결과에 따라, 동적 석출된 상은 모두 $\mathrm{Mg}_{2} \mathrm{Sn}$ 상이기 때문에 압출 후 전기비저항 값의 감소는 전적으로 $\mathrm{Mg}_{2} \mathrm{Sn}$ 의 동적 석출 에 의한 것으로 볼 수 있다. 이전 연구에 따르면, $\mathrm{Mg}-\mathrm{Sn}$ 계 합금을 압출 시 동적 석출을 통해 $1 \mathrm{wt} \%$ 의 $\mathrm{Mg}_{2} \mathrm{Sn}$ 상 이 형성될 때, 전기비저항 값은 $4.87 \mathrm{n} \Omega \mathrm{m}$ 만큼 감소하는 것으로 알려져 있다 [26]. 이러한 $\mathrm{Mg}_{2} \mathrm{Sn}$ 석출물 양과 전 기비저항 값의 상관관계를 이용하여, 균질화재와 압출재의 전기비저항 차이로 부터 $\mathrm{Mg}_{2} \mathrm{Sn}$ 석출물의 양을 계산할 수 있다. 그림 6(b)에 보이는 바와 같이, TZ71 합금에서의 $\mathrm{Mg}_{2} \mathrm{Sn}$ 석출물의 양은 $4.90 \mathrm{wt} \%$ 이고, TZA711 합금에서 는 $7.50 \mathrm{wt} \%$ 로, TZA711 합금에서 더 많은 석출물이 형 성되었다는 것을 알 수 있다. 이러한 결과는 그림 4의 압 출재 미세조직 관찰 결과와 잘 부합한다. 여기서 주목해야 할 점은 두 합금에 첨가된 $\mathrm{Sn}$ 의 양이 $7 \mathrm{wt} \%$ 로 동일함에 도 불구하고 형성된 $\mathrm{Mg}_{2} \mathrm{Sn}$ 석출물의 양이 상당한 차이를 보인다는 것이다. 이러한 결과는 두 가지 요인에서 기인한

Table 2. Chemical compositions and tensile properties of TZ71 and TZA711 alloys.

\begin{tabular}{c|c|c|c|c|c|c|c}
\hline \multirow{2}{*}{ Alloy } & \multicolumn{3}{|c|}{ Chemical composition (wt\%) } & \multicolumn{3}{c}{ Tensile properties } \\
\cline { 2 - 8 } & Sn & $\mathrm{Al}$ & $\mathrm{Zn}$ & $\mathrm{Mg}$ & YS (MPa) & UTS (MPa) & EL $(\%)$ \\
\hline TZ71 & 6.94 & - & 1.05 & Bal. & 197 & 265 & 10.8 \\
\hline TZA711 & 7.01 & 1.10 & 1.12 & Bal. & 257 & 321 & 13.1 \\
\hline
\end{tabular}


다고 볼 수 있다. 첫 번째로는, $\mathrm{Al}$ 의 첨가로 인한 $\mathrm{Sn}$ 의 고용량 감소로 인한 것으로, $\mathrm{Mg}-\mathrm{Sn}$ 계 합금에 $\mathrm{Al}$ 이 첨가되 면 $\mathrm{Mg}$ 기지 내에 $\mathrm{Sn}$ 의 고용량이 감소된다고 보고되고 있 다 [28,29]. 실제로 PANDAT software를 통해 구해진 평 형 상태도에서 계산한 결과, 압출 동안의 주 변형 구간에 서의 실제 온도로 여겨지는 $300{ }^{\circ} \mathrm{C}$ 에서의 $\mathrm{Sn}$ 고용도가 $\mathrm{TZ71}$ 합금에서는 $1.56 \mathrm{wt} \%$ 인 반면 TZA711 합금에서는 $1.41 \mathrm{wt} \%$ 로 나타났으며, 이는 $1 \mathrm{wt} \% \mathrm{Al}$ 첨가로 인해 $\mathrm{Sn}$ 고용량이 약 $9.6 \%$ 감소했음을 의미한다 (그림 6(b)). 동일한 압출온도에서 $\mathrm{Sn}$ 의 고용량이 감소한다는 것은 압 출 중에 더 많은 $\mathrm{Mg}_{2} \mathrm{Sn}$ 석출물이 형성된다는 것을 의미 한다. 따라서, $\mathrm{Al}$ 의 첨가로 인해 $\mathrm{Sn}$ 의 고용량이 감소한 TZA711 합금에서 더 많은 $\mathrm{Mg}_{2} \mathrm{Sn}$ 석출물이 형성된다. 두 번째 요인으로는 고용된 $\mathrm{Al}$ 원자들이 전위의 이동을 방해 하여 동적 석출 거동을 촉진시켰기 때문이다. 석출은 높은 에너지를 가지는 격자 결함(lattice defect)들에서 우선적으 로 형성되는데, 앞서 언급한 재결정 분율의 증가와 마찬가 지로 $\mathrm{Al}$ 용질 원자들이 압출 중에 전위의 엉킴과 축적을 가속화 시키고 이로 인해 동적 석출이 보다 용이해져 석출 물의 크기가 미세해지고 그 양 또한 증가하게 된다. 그리 고, TZ71 합금과 달리 TZA711 합금에서는 재결정된 영 역과 재결정되지 않은 영역 모두에서 동적 석출이 발생하 며 (그림 4), 이는 $\mathrm{Al}$ 용질 원자들로 인한 동적 석출 거 동의 촉진 효과가 재결정 여부와 상관없이 소재 전반에 걸 쳐 야기되기 때문이다.

그림 7은 TZ71과 TZA711 압출재의 상온 인장 곡선을 보여주는 것으로, 이에 해당하는 인장 물성 값은 표 2에 나타내었다. TZ71 압출재는 항복강도(yield strength, YS) $197 \mathrm{MPa}$, 최대인장강도(ultimate tensile strength, UTS) $265 \mathrm{MPa}$, 그리고 연신율(elongation) $10.8 \%$ 을 보였다. 반 면, TZA711 압출재는 항복강도, 최대인장강도, 연신율이 각각 $257 \mathrm{MPa}, 321 \mathrm{MPa}, 13.1 \%$ 로, $\mathrm{TZ71}$ 압출재보다 강도와 연신율이 모두 증가하였다. TZA711 압출재에서의 강도 증가의 주요 요인은 결정립 미세화과 동적 석출물의 양의 증가라고 볼 수 있다. $\mathrm{Al}$ 의 첨가에 의해 미세한 재 결정된 결정립의 분율이 증가하고 더 많은 석출물로 인한 결정립 성장 억제 효과가 증대하여 평균 결정립 크기가 $5.3 \mu \mathrm{m}$ 에서 $3.3 \mu \mathrm{m}$ 로 감소하게 된다. Hall-Petch relation 에 따라 결정립계 강화 효과가 크게 향상하여 강도가 향상 된다. 또한, $\mathrm{Al}$ 의 첨가에 의한 압출재에 형성되는 $\mathrm{Mg}_{2} \mathrm{Sn}$ 동적 석출물의 양이 $4.90 \mathrm{wt} \%$ 에서 $7.50 \mathrm{wt} \%$ 로 증가하여 석출 강화 효과 또한 향상된다. 이와 함께, 압출 후에도 기지 내에 고용되어 있는 $\mathrm{Al}$ 으로 인한 고용강화 효과 또

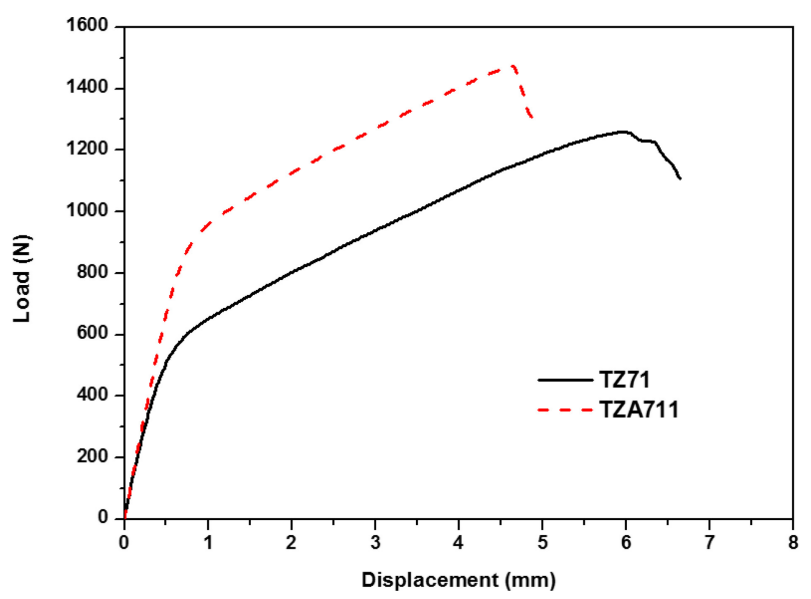

Fig. 8. 3-point bending load-displacement curves of TZ71 and TZA711 alloys.
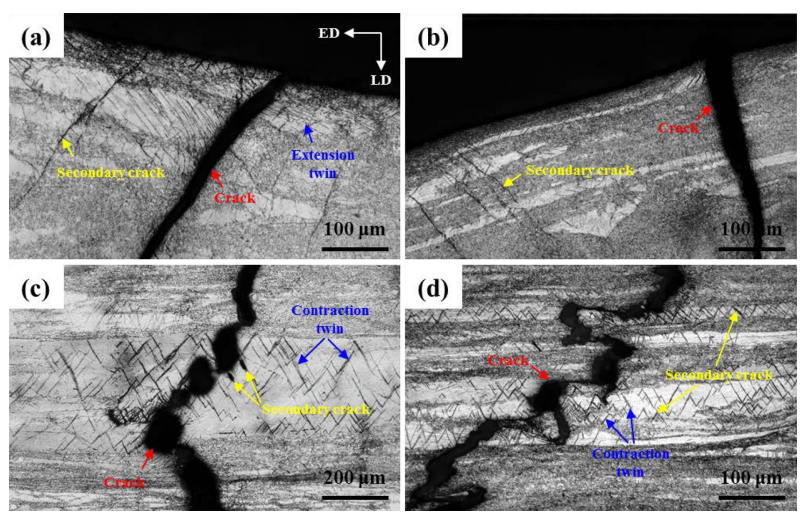

Fig. 9. Optical micrographs of $(a, b)$ intrados and (c,d) extrados regions of bending failed specimens: (a,c) TZ71 and (b,d) TZA711 alloys. ED and LD represent the extrusion direction and loading direction, respectively.

한 강도의 향상에 기여했을 것으로 판단된다. 따라서, $1 \mathrm{wt} \%$ 의 소량의 $\mathrm{Al}$ 첨가에도 불구하고 이러한 결정립계 강화 효과, 석출 강화 효과, 그리고 고용 강화 효과로 인 해 압출재의 항복강도가 $60 \mathrm{MPa}$, 최대인장강도가 56 $\mathrm{MPa}$ 크게 향상되었다. 일반적으로 강도와 연신율은 반비 례 관계를 가지고 있다고 알려져 있지만, TZA711 압출재 는 TZ71 압출재와 비교하여 강도 향상과 더불어 연신율도 향상되었다. 연신율의 향상은 압출재의 동적 재결정 분율 과 아주 밀접한 관련이 있다 [30,31]. 마그네슘 압출재는 일반적으로 기저면(basal plane)이 압출 방향과 평행하게 배열된 fiber basal texture가 형성되기 때문에 압출 방향 으로 인장 변형 시 $\mathrm{c}$ 축이 압축되는 응력상태가 되어 \{10-11\} contraction twin이 형성되고, 이후 $\{10-11\}$ contraction twin 내부에 $\{10-12\}$ extension twin이 형성 
되어 $\{10-11\}-\{10-12\}$ double twin이 형성된다 [32,33]. 인장 변형 전, 결정립의 기저면이 변형 방향과 평행하게 배열되어 기저면 슬립(basal slip)이 발생하기 어렵지만, 인 장 변형으로 인해 $\{10-11\}$ contraction twin과 $\{10-11\}-$ \{10-12\} double twin이 형성되면 쌍정 내부의 기저면은 변형 방향과 각 $56.2^{\circ}$ 와 $37.5^{\circ}$ 의 각도를 가지게 되어 슬립 이 용이해진다 $[34,35]$. 따라서, 쌍정 내부에서의 슬립으로 인해 전위가 쉽게 축적되어 응력집중(stress concentration) 이 야기되고 결국 미세균열(microcrack)이 발생하게 된다. 특히, $\{10-11\}-\{10-12\}$ double twin 내부의 $\{10-12\}$ extention twin의 계면에 전위가 축적되어 더 높은 응력집 중을 야기하게 된다. 쌍정의 형성은 결정립의 크기에 상당 히 의존적이며, 결정립 크기가 증가할수록 쌍정을 활성화 시키기 위한 응력(stress for activating twinning)이 감소하 여 쌍정이 쉽게 발생한다 [36,37]. 그러므로, 미세한 재결 정된 결정립보다 조대한 재결정되지 않은 결정립에서 미세 균열을 야기시키는 쌍정이 쉽게 형성되어 연신율이 감소된 다. 앞서 언급한 바와 같이, $\mathrm{Al}$ 첨가 시 조대한 재결정되 지 않은 결정립의 분율과 폭이 감소하고, 이로 인해 인장 변형 중에 쌍정의 형성이 억제되어 TZA711 압출재의 연 신율이 증가하게 되는 것이다.

그림 8은 TZ71과 TZA711 압출재의 굽힘 하중-변위 곡 선을 나타낸다. TZ71과 TZA711 압출재의 굽힘 항복 하 중(bending yield load)은 각각 $477 \mathrm{~N}$ 과 $841 \mathrm{~N}$ 이고, 최 대 굽힘 하중(maximum bending load)은 각각 $1259 \mathrm{~N}$ 과 $1475 \mathrm{~N}$ 이었다. TZA711 압출재에서 월등히 높은 굽힘 하중을 보여주고 있는데, 이것은 $\mathrm{Al}$ 의 첨가가 결정립계 강 화 효과, 석출 강화 효과 그리고 고용 강화 효과를 증대시 켜 인장강도를 항상시키는 결과와 잘 부합한다. 그러나, $\mathrm{Al}$ 의 첨가는 TZ71 압출재의 최대 굽힘 변형량 $6.6 \mathrm{~mm}$ 에서 TZA711 압출재의 최대 굽힘 변형량 $4.9 \mathrm{~mm}$ 로 감소하는 결과를 초래한다. TZA711 압출재가 인장시험에서 더 높은 연성을 가짐에도 불구하고, 굽힘시험에서는 더 낮은 굽힘 성을 나타내는 것은 두 시험들에서 최대 변형량이 결정되 는 요인이 서로 다르다는 것을 의미한다. 인장시험에서와 는 달리 3점 굽힘시험에서는 상부 핀과 맞닿는 부분인 시 편의 상부에서는 압축응력이 작용하고, 시편의 하부에서는 인장응력이 작용한다. 일반적으로, 기저면과 압출 방향이 평행하게 배열된 기저면 집합조직(fiber basal texture)을 가지는 마그네슘 압출재를 압출 방향과 수직한 방향으로 굽힘 하중을 가할 때, 상부에서 $\mathrm{c}$ 축이 인장되는 응력이 작용하여 \{10-12\} extension twin이 형성되는 반면, 하부 에서는 $\mathrm{c}$ 축이 압축되는 응력이 작용하여 주로 $\{10-11\}$ contraction twin과 $\{10-11\}-\{10-12\}$ double twin이 형성 된다 [38]. 그림 9에서 보여지듯이, TZ71 압출재의 상부에 서 쌍정이 쉽게 형성되는 조대한 재결정되지 않은 결정립 에서 \{10-12\} extension twin이 관찰된다. 하지만, TZA711 압출재의 상부에서 재결정되지 않은 영역에는 $\{10-12\}$ extension twin이 거의 관찰되지 않는다. 이러한 이유는 재결정되지 않은 결정립의 두께와 내부의 동적 석 출물의 차이에 기인한다. $\mathrm{Al}$ 의 첨가에 의해 TZA711 압출 재의 재결정되지 않은 결정립의 두께는 감소하기 때문에 결정립 크기가 감소하는 경우와 마찬가지로 쌍정을 활성화 시키기 위한 응력이 증가하게 된다. 게다가, $\mathrm{Al}$ 의 첨가에 의해 TZA711 압출재의 재결정되지 않은 영역에서 동적 석출이 촉진되는데, 이전 연구에 따르면 이미 형성된 석출 물들은 $\{10-12\}$ extension twin의 형성과 전파를 방해하는 역할을 한다고 알려져 있다 [39]. 이러한 이유들로 인해 TZA711 압출재에서는 재결정되지 않은 영역에서 변형을 수용해 줄 수 있는 $\{10-12\}$ extension twin이 거의 관찰 되지 않으므로 낮은 굽힘성을 나타낸다. 게다가, 두 압출재 모두 상부에서 굽힘 하중과 약 $45^{\circ}$ 의 각도를 이루는 이차 균열(secondary crack)이 관찰되고 같은 방향을 따라 균열 이 발생한 것을 볼 수 있다. 이 균열들은 상부에서 압축 응력 하에서 발생하는 전단띠(shear band) 현상에 의한 것 이다. 이 균열의 형성 또한 동적 석출물의 양과 평균 결정 립 크기와 관련이 있다. TZA711 압출재는 TZ71 압출재 보다 많은 동적 석출물과 작은 결정립 크기를 가지고 있기 때문에 굽힘시험 중에 석출물들과 결정립계 주변으로 전위 의 축적이 가속화된다. 그 결과, 전단띠 형성과 이로 인해 발생하는 균열이 더 쉽고 빠르게 형성되어 TZA711 압출 재의 굽힘성이 저하되는 것이다. 굽힘시험편의 하부의 경 우, 인장응력하에 있기 때문에 두 압출재 모두 재결정되지 않은 결정립에서 미세균열을 야기하는 $\{10-11\}$ contraction twin과 $\{10-11\}-\{10-12\}$ double twin이 형성된다. TZA711 압출재에서의 재결정 분율 증가는 이러한 쌍정들 의 형성을 억제하여 굽힘성이 향상될 수 있지만, 압축응력 이 작용하는 상부에서 많은 동적 석출물과 작은 결정립 크 기로 야기되는 $\{10-12\}$ extension twin 형성의 억제와 균 열의 조기 형성이 TZA711 압출재의 굽힘성을 저하시키는 데 중요한 요인들로 작용한다.

\section{4. 결 론}

본 연구에서는 $1 \mathrm{wt} \% \quad \mathrm{Al}$ 의 첨가가 $\mathrm{TZ71}$ 마그네슘 합 금 압출재의 미세조직과 기계적 특성에 미치는 영향을 동 
적 재결정과 동적 석출 거동의 관점에서 조사하여 다음과 같은 결론을 얻었다.

1. TZ71과 TZA711 압출재 모두 미세한 재결정된 결정 립과 조대한 재결정되지 않은 결정립이 혼재되어 있었으 나, $\mathrm{Al}$ 의 첨가에 따라 동적 재결정 거동이 촉진되어 TZA711 압출재가 TZ71 압출재보다 재결정 분율이 높으며 평균 결정립 크기가 미세해졌다.

2. $\mathrm{TZ71}$ 압출재에는 $\mathrm{Mg}_{2} \mathrm{Sn}$ 동적 석출물이 재결정된 결 정립계 주변에만 존재하였지만, TZA711 압출재에서는 시 편 전반에 걸쳐 석출물이 균일하게 분포하고 있었으며, $\mathrm{Al}$ 의 첨가에 의해 동적 석출물의 양이 증가하고 그 크기 또 한 미세해졌다.

3. $\mathrm{Al}$ 의 첨가에 의해 압출재의 강도와 연신율이 모두 크 게 증가하였다. 강도의 향상은 결정립 크기 감소, 석출물 양 증가, 고용 $\mathrm{Al}$ 원자의 의한 강화 효과 증대로 인한 것 이며, 연신율의 증가는 변형 쌍정이 쉽게 형성되는 조대한 재결정되지 않은 결정립의 분율이 감소했기 때문이다.

4. $\mathrm{Al}$ 첨가는 $\mathrm{TZ71}$ 압출재의 굽힘 하중을 향상시켰지만, 결정립 크기 감소와 석출물 양 증가로 야기되는 쌍정 형성 의 억제와 균열의 조기 형성으로 인해 굽힘 성형성은 저하 되었다.

\section{감사의 글}

이 논문은 2017년도 정부(미래창조과학부)의 재원으로 한 국연구재단의 지원을 받아 수행된 연구임(No. 2016R1 C1B2012140 and No. 2017R1A4A1015628).

\section{REFERENCES}

1. B. L. Mordike and T. Ebert, Mater. Sci. Eng. A 302, 37 (2001).

2. S. Ramakrishnan and P. Koltun, Resour. Conserv. Recy. 42, 49 (2004).

3. Z. B. Sajuri, Y. Miyashita, Y. Hosokai, and Y. Mutoh, Int. J. Mech. Sci. 48, 198 (2006).

4. S. W. Xu, M. Y. Zheng, S. Kamado, K. Wu, G. J. Wang, and X. Y. Lv, Mater. Sci. Eng. A 528, 4055 (2011).

5. D. L. Atwell and M. R. Barnett, Metall. Mater. Trans. A 38A, 3032 (2007).

6. F. R. Elsayed, T. T. Sasaki, T. Ohkubo, H. Takahashi, S. W. Xu, S. Kamado, and K. Hono, Mater. Sci. Eng. A 588, 318 (2013).

7. S. S. Park, W. N. Tang, and B. S. You, Mater. Lett. 64, 31
(2010).

8. W. L. Cheng, H. S. Kim, B. S. You, B. H. Koo, and S. S. Park, Mater. Lett. 65, 1525 (2011).

9. T. T. Sasaki, K. Yamamoto, T. Honma, S. Kamado, and K. Hono, Scr. Mater. 59, 1111 (2008).

10. S. H. Park, S.-H. Kim, H. S. Kim, J. H. Yoon, and B. S. You, J. Alloy. Compd. 667, 170 (2016).

11. S. H. Park, H. S. Kim, and B. S. You, Korean J. Met. Mater. 51, 637 (2013).

12. H. Yu, Y. M. Kim, B. S. You, H. S. Yu, and S. H. Park, Mater. Sci. Eng. A 559, 798 (2013).

13. H. -Y. Wang, J. Rong, G. -J. Liu, M. Zha, C.Wang, D. Luo, and Q. -C. Jiang, Mater. Sci. Eng. A 698, 249 (2017).

14. S. Meng, H. Yu, H. Zhang, H. Cui, S. H Park, W. Zhao, and B. S. You, Mater. Sci. Eng. A 690, 80 (2017).

15. Y. Du, M. Zheng, X. Qiao, W. Peng, and B. Jiang, Mater. Sci. Eng. A 673, 47 (2016).

16. Y. Z. Du, X. G. Qiao, M. Y. Zheng, K. Wu, and S. W. Xu, Mater. Sci. Eng. A 620, 164 (2015).

17. S. H. Park, H. Yu, J. H. Bae, C. D. Yim, and B. S. You, J. Alloy. Compd. 545, 139 (2012).

18. H. Yu, S. H. Park, B. S. You, Y. M. Kim, H. S. Yu, and S. S. Park, Mater. Sci. Eng. A 583, 25 (2013).

19. S. -H. Kim, J. -G. Jung, B. S. You, and S. H. Park, Mater. Sci. Eng. A 657, 406 (2016).

20. S. -H. Kim and S. H. Park, Mater. Sci. Eng. A 676, 232 (2016).

21. J. C. Tan and M. J. Tan, Mater. Sci. Eng. A 339, 124 (2003).

22. A. Galiyev, R. Kaibyshev, and G. Gottstein, Acta Mater. 49, 1199 (2001).

23. S. H. Park, H. Yu, H. S. Kim, J. H. Bae, C. D. Yim, and B. S. You, Korean J. Met. Mater. 51, 169 (2013).

24. S. H. Park and B. S. You, J. Alloy. Compd. 637, 332 (2015).

25. J. -G. Jung, S. H. Park, and B. S. You, J. Alloy. Compd. 627, 324 (2015).

26. F. R. Elsayed, T. T. Sasaki, C. L. Mendis, T. Ohkubo, and K. Hono, Mater. Sci. Eng. A 566, 22 (2013).

27. B. Kim, S. -M. Baek, H. Y. Jeong, J. G. Lee, and S. S. Park, J. Alloy. Compd. 660, 304 (2016).

28. S. H. Park, J. H. Bae, S.-H. Kim, J. H. Yoon, and B. S. You, Metall. Mater. Trans. A 46, 5482 (2015).

29. S. H. Park, S.-H. Kim, H. S. Kim, and B. S. You, J. Alloy. Compd. 648, 615 (2015).

30. Q. Ma, H. El Kadri, A. L. Oppedal, J. C. Baird, M. F. Horstemeyer, and M. Cherkaoui, Scr. Mater. 64, 813 (2011). 
31. L. Jiang, J. J. Jonas, A. A. Luo, A. K. Sachdev, and S. 34. A. Ghaderi and M. R. Barnett, Acta Mater. 59, 7824 (2011). Godet, Scr. Mater. 54, 771 (2006).

32. M. R. Barnett, Z. Keshavarz, A. G. Beer, and X. Ma, Acta Mater. 56, 5 (2008).

33. S. W. Xu, S. Kamado, N. Matsumoto, T. Honma, and Y. Kojima, Mater. Sci. Eng. A 527, 52 (2009).

35. Y. Chino, K. Kimura, and M. Mabuchi, Mater. Sci. Eng. A 486, 481 (2008).

36. L. Jin, J. Dong, J. Sun, and A. A. Luo, Int. J. Plasticity 72 , 218 (2015).

37. J. B. Clark, Acta Metall. 16, 141 (1968). 